\author{
Review Article
}

\title{
Utilization of Renewable and Waste Materials for Biodiesel Production as Catalyst
}

\author{
Prashant Kumar $^{1 *}$, Anil K. Sarma², M.K. Jha1, Ajay Bansal ${ }^{1}$, \\ Bharvee Srivasatava ${ }^{3}$ \\ ${ }^{1}$ Department of Chemical Engineering, Dr B R Ambedkar National Institute of Technology \\ Jalandhar-144011, India \\ ${ }^{2}$ Chemical Conversion Division, Sardar Swaran Singh National Institute of Renewable Energy, \\ Kapurthala, Punjab-144601, India \\ ${ }^{3}$ Department of Chemical Engineering, S.D. College of Engineering and Technology \\ Muzaffarnagar-251001, India
}

Received: 25th May 2015; Revised: 17th June 2015; Accepted: 10 th July 2015

\section{Abstract}

The efficient and economic utilization of natural renewable and waste materials of various industries and biomass having non-homogeneous composition is a new dimension of research for biodiesel production. A combination of these renewable, waste materials and traditional heterogeneous catalyst can also be looked after for the possible solution of heterogeneous catalytic transesterification. This review discusses industrially derived and naturally occurring materials containing calcium, sodium, potassium etc, which were found instrumental for biodiesel production. About 60 research articles and patents have been reviewed and the findings are analysed in this article for developing industrial scale heterogeneous catalytic pilot plant facilities for biodiesel production. (C) 2015 BCREC UNDIP. All rights reserved.

Keywords: Biodiesel; Renewable and Waste Material; Calcium; Potassium

How to Cite: Kumar, P., Sarma, A.K., Jha, M.K., Bansal, A., Srivasatava, B. (2015). Production Utilization of Renewable and Waste Materials for Biodiesel Production as Catalyst. Bulletin of Chemical Reaction Engineering \& Catalysis, 10 (3): 221-229. (doi:10.9767/bcrec.10.3.8584.221-229)

Permalink/DOI: http://dx.doi.org/10.9767/bcrec.10.3.8584.221-229

\section{Introduction}

In recent years catalysis research for biodiesel production was gaining growing attention due to rapid expansion of biofuels market all over the world. Catalysts employed in biodiesel production can be divided into three categories based upon the chemical characteristics, namely acidic, alkali and enzymatic catalyst. Enzymatic catalysts are instrumental in restricting soap formation and product refining process is easier to complete. However, the cost

* Corresponding Author

E-mail: prashant.kumar87@gmail.com (P. Kumar) and longer reaction time restricts the use of enzymatic catalyst for commercial purposes [1$12]$.

The catalyst can also be divided into two broad categories depending upon their physical properties during the course of reaction. If the catalyst remains in the same phase (i.e. miscible) with the reactants, it is called the homogeneous catalytic transesterification reaction. On the other hand, if the catalyst remains in different phase to that of the reactants (immiscible), it is called the heterogeneous catalytic transesterification [10-13]. The general classification of the catalyst is as shown in Figure 1. 


\section{Homogenous Catalyst}

Homogenous catalyst is mixed with a solvent to use in a reaction system. Effectiveness of homogeneous catalyst is more for low FFA containing oils for transesterification reaction than for high FFA containing oils that facilitate soap formation in the former. Sulfuric Acid, phosphoric acid, organic sulfonic acid and hydrochloric acids are mostly used as acid homogenous catalysts. Sodium hydroxide, potassium hydroxide and their alkoxides are commonly employed alkali homogeneous catalyst. Acid catalyst is less effective for transesterification reaction than alkali catalysis. Demerits of homogeneous catalysis include separation of catalyst from the reaction mixture, excess use of water for washing the ester phase and corrosive nature of the catalyst demanding corrosion free reactors $[2,13]$.

\section{Heterogeneous Catalyst}

Heterogeneous catalyst is employed to address issues of homogeneous catalyst. Hetero- geneous catalyst is also referred as surface catalyst as reaction occurs on the catalyst surface. Transesterification reaction if occurring in the presence of heterogeneous catalyst, the reactants diffuse through the reaction mixture and adsorb onto the catalyst surface [14].

Heterogeneous solid catalyst is more economical than homogeneous liquid catalyst because these can be reused several times and additionally both transesterification and esterification can be carried out side by side. Heterogeneous catalyst is required less in quantity as compared to homogeneous catalyst, as for production of 100 tonnes of biodiesel, 10 tones of sodium hydroxide may be required; while only 5.7 tonnes of solid supported $\mathrm{MgO}$ is sufficient for production of 100,000 tonnes of biodiesel [15].

Demerit of heterogeneous catalyst is presence of three different phases in the reaction system as catalyst solid, oil-liquid and alcohol after heating vapor which decrease diffusion at high temperatures and long reaction times to overcome diffusion problems owing to the for-

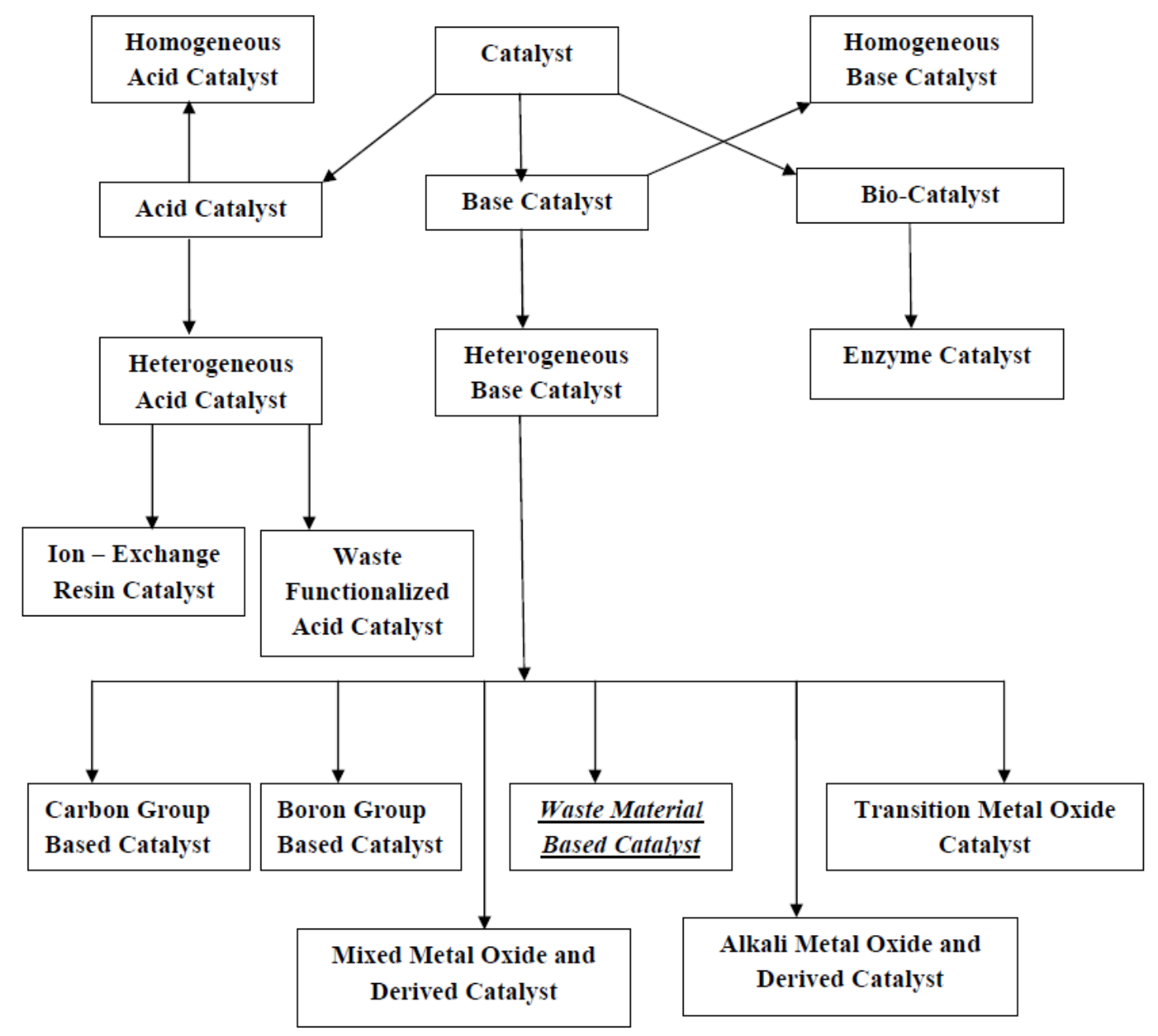

Figure 1. Classification of catalysts 
mation of three phases of the reactants [16].

A number of solid acids have been investigated for transesterification reaction. But challenge still lies in stability of acid sites and control of surface properties so that oily compounds diffuse towards acid sites. This phenomenon helps in leaving polar compounds (glycerol and water, etc.) from the catalyst basic structure. Solid acid catalyst has various acidic sites with different concentration of Brönsted or Lewis-acidity as compared to the homogenous acid catalysts $[17,18]$.

The reported literature in the last decades unveil that several researchers worked in base catalysis for the production of biodiesel. Calcium carbonate rock was used as catalyst by Suppes et al. [19] for transesterification of vegetable oils and achieved conversion of $78 \%$ at $513 \mathrm{~K}$ and $>95 \%$ at $533 \mathrm{~K}$. Kim et al. [20] prepared a solid super base of $\mathrm{Na} / \mathrm{NaOH} /-\mathrm{Al}_{2} \mathrm{O}_{3}$ which showed comparable catalytic activity like $\mathrm{NaOH}$ catalyst under the optimized reaction conditions.

The reaction mechanism for alkali-catalyzed transesterification was formulated in three steps. The first step is the reaction of the base with the alcohol, producing an alkoxide and the protonated catalyst. The nucleophilic attack of the alkoxide at the carbonyl group of the triglyceride generates a tetrahedral intermediate, from which the alkyl ester and the corresponding anion of the triglyceride are formed. The catalyst later deprotonates and reacts with the second molecule of alcohol and starts another catalytic cycle. Diglycerides and monoglycerides are converted by the same mechanism to a mixture of alkyl esters and glycerol [21, 22].

Heterogeneous catalytic transesterification, on the other hand, completes in cycles due to the polarity arises in the catalyst having substantial amount of covalent characters. The catalytic functions varies from catalyst to catalyst, as reported in several literatures [23, 13]. Strontium oxide ( $\mathrm{SrO}$ ) has been regarded as a very effective one among the base heterogeneous catalyst for transesterification with about $96 \%$ conversion of cooked oil to biodiesel under microwave radiation at $1 \%$ loading as reported in several literature [24,25]. Nevertheless, the monetary value of pure $\mathrm{SrO}$ is very high and reusability is another shortage of this stuff [26].

Unfortunately, the synthesis of highly active heterogeneous catalysts is complex, costly, and requires special skills to operate. Therefore, it is a great challenge to explore an ideal solid basic catalyst that is highly effective, low-cost, and ecologically friendly for the promising biodiesel production [27, 28].

To overcome all these issues, utilization of natural renewable and waste materials of various industries having non-homogeneous composition as an economic catalyst has been a new trend for biodiesel production. A combination of these renewable, waste materials and traditional heterogeneous catalyst can also be looked after for the possible solution of heterogeneous catalytic transesterification.

There are several natural calcium sources, such as: different kinds of ashes obtained from renewable precursors, shells, and bones, etc., widely used as raw materials for catalyst synthesis that could eliminate the wastes and simultaneously produces catalysts with high cost effectiveness. $\mathrm{CaO}$ catalyst derived from these waste materials could be a potential candidate for biodiesel production [29-31]. Similarly, plants derived $\mathrm{Na}_{2} \mathrm{O}, \mathrm{K}_{2} \mathrm{O}$ or $\mathrm{CaO}$ could be very effective with silica support for transesterification. Various kinds of ashes found instrumental in catalyzing transesterification reaction, such as: industrial waste fly ash, wood ash, aquatic plant waste ash, etc.

\subsection{Renewable Feedstock Based Fly Ash}

Ho et al., [32-33] reported that calcium oxide $(\mathrm{CaO})$ could be potentially used as a support for palm oil mill fly ash to be implemented for transesterification reaction from crude palm oil (CPO). Optimum conditions were found to be at $850{ }^{\circ} \mathrm{C}$ for $2 \mathrm{~h}$ with $45 \mathrm{wt} . \%$ loading of calcined calcium carbonate $\left(\mathrm{CaCO}_{3}\right)$ for catalyst preparation. It was determined that transesterification conditions of $6 \mathrm{wt} . \%$ catalyst loading, $12: 1$ methanol to oil molar ratio, $45{ }^{\circ} \mathrm{C}$ reaction temperature, $3 \mathrm{~h}$ reaction time and 700 rpm stirring speed resulted in biodiesel yield and FAME conversion of $79.76 \%$ and $97.09 \%$, respectively. The developed catalyst could feasibly be used up to three consecutive cycles after regeneration using methanol washing followed by recalcination at $850{ }^{\circ} \mathrm{C}$ for $2 \mathrm{~h}$. The $\mathrm{CaCO}_{3}$ converted to $\mathrm{CaO}$ at $770{ }^{\circ} \mathrm{C}$ and interacted well with the ash support. The material obtained so was employed in the transesterification of palm oil with methanol to yield biodiesel. The catalyst prepared by loading of 15 wt\% calcined $\mathrm{CaCO}_{3}$ at a fixed temperature of $800{ }^{\circ} \mathrm{C}$ on fly ash exhibited a maximum oil conversion of $94.48 \%$.

Boey et al. [34] reported that empty fruit bunch based boiler ash (BA) is a possible catalyst for biodiesel production from palm olein. Optimum reaction conditions were found to be 
3 wt.\% catalyst, 15:1 methanol: oil molar ratio, reaction temperature of $60{ }^{\circ} \mathrm{C}$ and reaction time of $30 \mathrm{~min}$ for $90 \%$ methyl esters. The BA was prepared for transesterification by drying in oven at $105 \pm 2{ }^{\circ} \mathrm{C}$ to constant weight.

\subsection{Ashes from Pure Biomass Resources}

Chouhan and Sarma [35] utilized L. Perpusilla Torrey ashes obtained from combustion which was further calcined at $550 \pm 5{ }^{\circ} \mathrm{C}$ before use as catalyst for transesterification of refined Jatropha curcas L. oil (JCO) with methanol. The catalyst was found to be rich in potassium (11.3\%) in addition to other non-metal and metallic contents. Optimum reaction parameters for biodiesel production was found $65 \pm 5{ }^{\circ} \mathrm{C}$ in 5 $\mathrm{h}$ at 1:9 $\mathrm{M}$ ratio of oil to alcohol with $5 \%$ of the ash as catalyst for $89.43 \%$ conversion. Reusability of the catalyst was found up to 3 times but there is a reduction of efficacy by about $25 \%$ for $3^{\text {rd }}$ consecutive batch reaction.

Sharma et al. [36] utilized wood ash, which is a highly alkaline material as catalyst for transesterification reaction in pure and further activated with $\mathrm{K}_{2} \mathrm{CO}_{3}$ and $\mathrm{CaCO}_{3}$ by double carbonate solid state reaction to yield activated wood ash catalysts (AWC). The wood ash was calcined in a temperature range of $500-1200{ }^{\circ} \mathrm{C}$ to produce calcined wood ash catalysts (CWC). Transesterification of JCO with the help of CWC and AWC resulted in FAME range of 97 $99 \%$. At reaction conditions of oil: methanol ratio (1:12 molar ratio) mixture to maintain catalytic activity at $40{ }^{\circ} \mathrm{C}$ for $15 \mathrm{~min}$. To the above stirred solution, desired quantity of vegetable oil was added and the reaction temperature was set at $65^{\circ} \mathrm{C}$ for the experiment.

Yaakob et al. [37] transesterified JCO, in the presence of ash generated from Palm empty fruit bunch (EFB). $\mathrm{KOH}$ was impregnated on EFB to achieve a potassium level of 20 wt.\%. Optimum reaction conditions were found to be for EFB-catalyzed reaction, i.e. temperature of $65{ }^{\circ} \mathrm{C}$, oil/methanol ratio of $15,90 \mathrm{~min}, 20 \mathrm{wt} . \%$ EFB ash catalyst and the KOH-EFB-catalyzed reactions $65{ }^{\circ} \mathrm{C}$, oil/methanol ratio of 15 , reaction time of $45 \mathrm{~min}$, and $15 \mathrm{wt} \%$ of $\mathrm{KOH}$ doped ash, a yield of more than $98 \%$ was achieved with both the catalyst.

Chen et al. [38] utilized calcined egg shell as catalyst and rise husk (RHA) as its support. It was employed to transesterify palm oil into biodiesel catalytically. Catalytic activity of 30\% RHA $800-800$ was found best among the catalyst prepared. Reaction conditions of reaction time of $4 \mathrm{~h}$, methanol to oil molar ratio 9:1, and catalyst loading of $7 \mathrm{wt} . \%$, the biodiesel yield could reach 91.5\%.Catalyst can be reused 8 times and it was instrumental in getting $80 \%$ biodiesel yield.

Vadery et al. [39] reported catalyst coconut husk derived by mean of controlled heating. The main active component over the catalyst was found to be potassium. It was found that temperature of $45{ }^{\circ} \mathrm{C}$, with the catalyst prepared by the calcination at $350{ }^{\circ} \mathrm{C}$ of coconut husk yield of biodiesel was found to be more than $97 \%$ within 30 min of reaction time.

Kumar et al. [40] utilized, ash obtained from a typical thermal power plant operated using a solid biomass mixture as fuel, called BiomassBased Thermal Power Plant Fly Ash (BBTPFS) as catalyst for transesterification of Jatropha curcas oil (JCO) having a high percentage of free fatty acids (FFA). It was observed that at a temperature of $225{ }^{\circ} \mathrm{C}$ and an internal vapor pressure of $3.2 \mathrm{MPa}$ in a batch reactor with $5 \%$ catalyst loading, 1:9 molar ratio of oil to alcohol and $3 \mathrm{~h}$ reaction time, the optimum yield of biodiesel obtained was $93.9 \%$.

Sarma et al. [41] utilized Musa balbisiana Colla underground stem (MBCUS) ash catalyst, in a high pressure-high temperature (HT) reactor to transesterify high FFA containing JCO. The catalyst was instrumental and effective during transesterification under HT (275 ${ }^{\circ} \mathrm{C}$ ) and internal pressure (4.2 MPa) and 98.0\% fatty acid methyl ester (FAME) could be obtained from JCO with an initial acid value (AV) $18.4 \mathrm{mg} \mathrm{KOH} / \mathrm{g}$. There was a drastic reduction of FFA (AV $3.4 \mathrm{mg} \mathrm{KOH} / \mathrm{g}$ ) in the FAME obtained.

\subsection{Waste Bones}

Chakraborty et al. [42] investigated waste Rohu fish (Labeo rohita) bone ashes for transesterification reaction as high-performance, reusable, low-cost heterogeneous catalyst for synthesis of biodiesel from soybean oil. It was reported that main constitute of fish, i.e. HAP (hydroxyapatite $\left[\mathrm{Ca}_{10}\left(\mathrm{PO}_{4}\right)_{6}(\mathrm{OH})_{2}\right]$ ), converts into $\beta$-tri-calcium phosphate when calcined above $900{ }^{\circ} \mathrm{C}$ for $2 \mathrm{~h}$. Optimal reaction conditions were reported as methanol/oil molar ratio of $6.27: 1$, calcination temperature of $997.42{ }^{\circ} \mathrm{C}$ and catalyst concentration of $1.01 \mathrm{wt} . \%$ of oil for $97.73 \%$ of biodiesel yield. The reusability of the catalyst shows that it could be reemployed up to six times.

Obadiah et al. [43] implemented waste animal bones as a cost effective catalyst for the transesterification of palm oil. Calcination of catalyst was done at various temperatures to convert calcium phosphate in the bones to hy- 
droxyapatite and $800{ }^{\circ} \mathrm{C}$ was found to give the best yield of biodiesel. Highest yield of FAME (96.78\%) was obtained at 20 wt.\% of catalyst, $1: 18$ oil to methanol molar ratio, $200 \mathrm{rpm}$ of stirring of reactants and at a temperature of $65^{\circ} \mathrm{C}$, in $4 \mathrm{~h}$.

Farooq et al. [44] investigated waste chicken bones as catalyst for biodiesel production with waste cooking oil. The experimental results suggested catalyst calcined at $900{ }^{\circ} \mathrm{C}$ showed good catalytic activity in the transesterification of WCO, providing maximum biodiesel yield of $89.33 \%$ at $5.0 \mathrm{~g}$ of catalyst loading, $15: 1$ methanol to oil molar ratio at temperature of $65{ }^{\circ} \mathrm{C}$ in reaction. The catalyst can be reused up-to four times.

\subsection{Waste Shells}

Boro et al. [45, 46] used mustered oil for biodiesel production with the help of a solid oxide catalyst derived from Turbonilla striatula waste shells. The shells were calcined at different temperatures for $4 \mathrm{~h}$. Formation of solid oxide, i.e. $\mathrm{CaO}$, was confirmed at calcination temperature of $800{ }^{\circ} \mathrm{C}$. The effect of the molar ratio of methanol to oil, the reaction temperature, catalyst calcinations temperature and catalyst amount used for transesterification were studied to optimize the reaction conditions. Biodiesel yield of $93.3 \%$ was achieved when transesterification was carried out at $65 \pm 5^{\circ} \mathrm{C}$ by employing 3 wt.\% catalyst and 9:1 methanol to oil molar ratio. Further the catalyst was modified doping it with varying the amount of $\mathrm{Ba}(0.5$ to 1.5 wt \%). Ba doped $\mathrm{CaO}$ was used as heterogeneous catalyst in the transesterification of waste cooking oil (WCO). The catalyst lost a bit active site so as the basicity for reuse. The optimum reaction condition obtained for achieving maximum conversion $>98 \%$ were $6: 1$ methanol to oil molar ratio, $3 \mathrm{~h}$ of reaction time, $1.0 \mathrm{wt} \%$ catalyst amount and $65{ }^{\circ} \mathrm{C}$ reaction time.

Empikul et al. [47] reported the solid oxide catalysts derived from the industrial waste shells of egg, golden apple snail, and meretrix venus and were used as catalyst for transesterification of palm olein oils. The waste materials calcined in air in optimum conditions (temperature of $800{ }^{\circ} \mathrm{C}$, time of $2-4 \mathrm{~h}$ ), transformed calcium species in the shells into active $\mathrm{CaO}$ catalysts. All catalysts derived from egg and mollusk shells at $800{ }^{\circ} \mathrm{C}$ provided high activity (>90\% fatty acid methyl ester (FAME) in $2 \mathrm{~h}$ ). These abundant wastes showed good potential to be used as biodiesel production catalysts.

$\mathrm{Hu}$ et al. [48] reported catalyst derived from waste freshwater mussel shell (FMS) which was prepared by a calcination-impregnationactivation method. The catalyst prepared so was applied in transesterification of Chinese tallow oil. The optimal calcination and activity temperature are $900{ }^{\circ} \mathrm{C}$ and $600{ }^{\circ} \mathrm{C}$, respectively. When the reaction is carried out at $70{ }^{\circ} \mathrm{C}$ with a methanol/oil molar ratio of $12: 1$, a catalyst concentration of $5 \%$ and a reaction time of $1.5 \mathrm{~h}$, the FMS-catalyst is active for 7 reaction cycles, with the biodiesel yield above $90 \%$.

Suryaputra et al. [49] reported the waste Capiz shell as raw material for catalyst production for biodiesel preparation. During calcination process, the calcium carbonate content in the waste capiz shell was converted to $\mathrm{CaO}$. This calcium oxide was used as catalyst for transesterification reaction between palm oil and methanol to produce biodiesel. The biodiesel preparation was conducted under the following conditions: the mole ratio between methanol and palm oil was 8:1, stirring speed was $700 \mathrm{rpm}$, and reaction temperature was 60 ${ }^{\circ} \mathrm{C}$ for 4,5 , and $6 \mathrm{~h}$ reaction time. The amount of catalyst was varied at $1,2,3,4$, and $5 \mathrm{wt} \%$. The maximum yield of biodiesel was $93 \pm 2.2 \%$, obtained at $6 \mathrm{~h}$ of reaction time and $3 \mathrm{wt} \%$ of amount of catalyst. In order to examine the reusability of catalyst developed from waste of capiz (Amusium cristatum) shell, three transesterification reaction cycles were also performed.

Niju et al. [50] reported that a laboratory scale continuous flow jacketed reactive distillation (RD) unit was developed to evaluate the performance of calcium oxide $(\mathrm{CaO})$ derived from egg shells as a heterogeneous catalyst for transesterification of waste frying oil. The effects of reactant flow rate, methanol to oil ratio and catalyst bed height on methyl ester conversion were investigated. All the experimental investigations were carried out at atmospheric pressure and the reboiler temperature was maintained at $65^{\circ} \mathrm{C}$ throughout the process. The results indicated that the system reached the steady state at $7 \mathrm{~h}$. Egg shell based $\mathrm{CaO}$ showed high catalytic activity in a continuous flow jacketed reactive distillation system and a maximum methyl ester conversion of $93.48 \%$ was obtained at a reactant flow rate of $0.2 \mathrm{ml}$ $\min ^{-1}$, methanol to oil ratio of $4: 1$ and catalyst bed height of $150 \mathrm{~mm}$.

Xie et al. [51] reported a novel high performance solid biodiesel catalyst derived from biont shell has been prepared by a tri-step procedure: incomplete carbonization-KF impregnationactivation. The effects of carbonization temperature, concentration of $\mathrm{KF}$ solution and activation temperature on the activity of the cata- 
lyst were investigated. The activity of the biont shell catalyst was evaluated by transesterification of rapeseed oil with methanol and the mechanism of catalytic activity is discussed. The results indicate that the transesterification yield of rapeseed oil to biodiesel reaches $97.5 \%$ with 3 hours reaction and 3 wt.\% catalyst dosage (based on rapeseed oil mass). The activity of the catalyst for the transesterification came from the active sites formed by reaction of incompletely carbonized biont shell with KF in the procedure of synthesis catalyst. The matrix of the biont catalyst is weakly polar in nature, favoring transesterification of rapeseed oil to biodiesel and hindering the reverse glycerolysis reaction. Therefore, the biont catalyst displayed a higher catalytic activity compared with conventional solid base catalysts tested for biodiesel production.

Konwar et al. [52, 53] discussed oil-cake waste (OCW) and carbonized de-oiled seed waste cake (DOWC) derived catalysts for biodiesel production. OCW catalyst sulfonated carbon materials were utilized as catalysts for pretreatment of acid oils. The DOCW catalyst reported to be utilized to convert free fatty acids (FFA) present in acid oils into corresponding methyl esters within $6-8 \mathrm{~h}$ at $80 \circ \mathrm{C}$, thus reducing the FFA content to desirable levels below 2 wt\%. Furthermore, the DOWC catalyst showed excellent activity in two reactions of interest in biomass conversion: cellulose saccharification (glucose yield 35-53\%) and fatty acid esterification (conversion up to 97\%).

Yang et al. [54] studied an eco-friendly shrimp shell catalyst for biodiesel production. Catalyst was prepared with incomplete carbonization of shrimp shell, loading KF on the resultant, and activation at a desired temperature. The catalytic activity was verified by the transesterification of rapeseed oil with methanol. The results indicated that the optimum preparation conditions were carbonization at $450{ }^{\circ} \mathrm{C}$, loading $\mathrm{KF}$ of $25 \mathrm{wt} \%$, and activation at $250{ }^{\circ} \mathrm{C}$. The conversion reached $89.1 \%$ using the shrimp shell catalyst when the reaction was carried out at $65{ }^{\circ} \mathrm{C}$ with a catalyst amount 2.5 wt \%, a methanol/rapeseed oil molar ratio 9:1, and a reaction time of $3 \mathrm{~h}$.

Shang et al. [55] used a peanut shell-derived solid acid of amorphous carbon bearing $\mathrm{SO}_{3} \mathrm{H}$, $\mathrm{COOH}$, and phenolic $\mathrm{OH}$ groups has been prepared by a one-step process. The effects of preparation conditions on the activity of the solid acid were investigated. The catalysts were characterized by scanning electron microscopy, X-ray diffraction, Fourier transform infrared spectroscopy, and thermogravimetric analysis. This catalyst showed high activity in the esterification of oleic acid with methanol. Under the optimal reaction conditions, a biodiesel yield of $98 \%$ could be obtained. Additionally, after six repeated uses, more than $95 \%$ yield of biodiesel was obtained, which indicated that the catalyst has a highly operational stability.

Recently available patents on the renewable waste material based catalysts have been tabulated as shown in Table 1.

\section{Concluding Remarks, Recommenda- tions and Future Work}

In general, waste material based heterogeneous catalysts were reported to be very effective for transesterification due to the presence of active basic functionalities in their composition. Very recently, researcher were also interested to modify and regenerate such catalyst using acidic functional groups upon the active carbon site of such materials [60]. However, the catalytic efficacy of most of the catalysts reported in literature are based upon lab-scale experimental facilities. While, only few have been conducted in the bench-scale facilities, and very few reached at the pilot-scale level. Thus, appropriate research thrust leading to pilot-scale development with such catalysts should be emphasized so as to practically demonstrate and evaluate the economics of these technologies. The catalyst leaching may be further reduced with the use of appropriate binding materials with the catalyst. The versatile composition of the catalysts may also enable its study for hydro processing, decarboxylation or

Table 1. Some of the important patents of renewable precursor based heterogeneous catalyst applied for transesterification and purification of product

\begin{tabular}{clcc}
\hline No. & \multicolumn{1}{c}{ Waste Material } & Inventors & Patent No. \\
\hline 1 & Rice Hull Ash & Turkay et al. [56] & US 20060269464 A1 \\
2 & Fresh Natural Seashell & Sarin et al. [57] & WO 2010113011 A2 \\
3 & Egg Shells & Sarin et al. [57] & WO 2010113011 A2 \\
4 & Swill-Cooked Dirty Oil & Liu et al. [58] & CN 101985104 B \\
5 & Egg Shells+Red Mud & Fang et al. [59] & CN 103396842 A \\
\hline
\end{tabular}


hydrogenation of vegetable oil for the production of green fuels and chemicals.

The use of these biodiesel in CI engine as B100 or of blended form with petroleum diesel for short and long duration study is recommended for future course of work. As a future recommendation the crude glycerol can be used as diesel addition. Glycerol can also be used in food industry, pharmaceutical industry, and personal care applications, etc. after treatment and purification.

\section{Conclusion}

In general waste material derived catalysts, such as: industrial waste fly ash, wood ash, aquatic plant waste ash, waste bones of animals (aquatic and terrestrial) and fish, waste shells, rice hull ash and egg shell, etc., werefound in several literature and patents which are widely used for transesterification of vegetable oil. These materials have active catalytic sites in their composition. Some of the catalysts were having modified active acidic sites in the decomposed carbon structure, having solid acid functionalities and character that directly helps in the transesterification of vegetable oil under long term treatment. Meanwhile, others were having active alkali, alkaline earth and non-transitional metal oxides in silica support that facilitate transesterification reactions at relatively higher temperature and pressure as compared to homogeneous catalyst.

\section{Acknowledgments}

The first author acknowledges MHRD-Govt of India for PhD Fellowship provided by them.

\section{References}

[1] Jothiramalingam, R., Wang, M. K. (2009). Review of Recent Developments in Solid Acid, Base, and Enzyme Catalysts (Heterogeneous) for Biodiesel Production via Transesterification. Industrial \& Engineering Chemistry Research. 48: 6162-6172.

[2] Atabani, A.E., Silitonga, A.S., Ong, H.C., Mahlia, T.M.I., Masjuki, H.H., Badruddin, I. A., Fayaz, H. (2013). Non-edible vegetable oils: A critical evaluation of oil extraction, fatty acid compositions, biodiesel production, characteristics, engine performance and emissions production. Renewable and Sustainable Energy Reviews. 18: 211-245.

[3] Mat, R., Ling, O. S., Johari, A., Mohamed, M. (2011). In Situ Biodiesel Production from Residual Oil Recovered from Spent Bleaching Earth. Bulletin of Chemical Reaction Engineering \& Catalysis. 6 (1): 53-57, doi: 10.9767/ bcrec.6.1.678.53-57.

[4] Giovanna, L., Roberto, A. B., José, A. D. R., Suzana, M. R.,Marcelo, Z. (2012). Effect of Feed Strategy on Methane Production and Performance of an AnSBBR Treating Effluent from Biodiesel Production. Applied Biochemistry and Biotechnology.166: 2007-2029.

[5] Sharma, S., Rangaiah G.P. (2012). Multiobjective optimization of a bio-diesel production process. Fuel, 103: 269-277. doi 10.1016/j.fuel.2012.05.035.

[6] Sankaranarayanan, T.M., Pandurangan, A., Banu, M., Sivasanker, S. (2011). Transesterification of sunflower oil over $\mathrm{MoO}_{3}$ supported on alumina. Applied Catalysis A: General. 409-410: 239-247.

[7] Murugesan, A., Umarani, C., Subramanian, R., Nedunchezhian, N. (2009). Bio-diesel as an alternative fuel for diesel engines-A review. Renewable and Sustainable Energy Reviews. 13: 653-662.

[8] Gunatilake, H., Roland-Holst, D., Sugiyarto, G. (2014). Energy security for India: Biofuels, energy efficiency and food productivity. Energy Policy. 65: 761-767.

[9] Reinoso, D.M., Damiani, D.E., Tonetto, G.M. (2014). Zinc glycerolate as a novel heterogeneous catalyst for the synthesis of fatty acid methyl esters. Applied Catalysis B: Environmental. 144: 308-316.

[10] López, D.E., Suwannakarn, K., Bruce, D.A., Goodwin Jr., J.G. (2007). Esterification and transesterification on tungstated zirconia: Effect of calcination temperature. Journal of Catalysis. 247: 43-50.

[11] Bello, E.I., Mogaji, T.S., Agge, M. (2011). The effects of transesterification on selected fuel properties of three vegetable oils. Journal of Mechanical Engineering Research. 3(7): 218225.

[12] Lam, M.K., Lee, K.T., Mohamed, A.R. (2010). Homogeneous, Heterogeneous and Enzymatic Catalysis for Transesterification Of High Free Fatty Acid Oil (Waste Cooking Oil) To Biodiesel: A Review. Biotechnology Advances 28: 500-518.

[13] Chouhan, A.P.S., Sarma, A.K. (2011). Modern heterogeneous catalysts for biodiesel production: A comprehensive review. Renewable and Sustainable Energy Reviews. 15: 4378-4399.

[14] Lam, M.K., Lee, K.T., Mohamed, A.R. (2010). Homogeneous, heterogeneous and enzymatic catalysis for transesterification of high free fatty acid oil (waste cooking oil) to biodiesel: A review. Biotechnology Advances. 28: 500-518.

[15] Semwal, S., Arora, A.K., Badoni, R.P., Tuli, D. K. (2011). Biodiesel production using hetero- 
geneous catalysts. Bioresource Technology. 102: 2151-2161.

[16] Meher, L.C., Dharmagadda, V.S.S., Naik, S.N. (2006). Optimization of alkali-catalyzed transesteriWcation of Pongamia pinnata oil for production of biodiesel. Bioresource Technology. 97: 1392-1397.

[17] Endalew, A.K., Kiros, Y., Zanzi, R. (2011). Heterogeneous catalysis for biodiesel production from Jatropha curcas oil (JCO). Energy. 36: 2693-2700.

[18] de Mattos, F.C.G., da S. de Souza, J.A., do A. Cotrim, A.B., de Macedo, J.L., Dias, J.A., Dias, S.C.L.; Ghesti, G.F. (2012). Lewis acid/surfactant rare earth trisdodecylsulfate catalysts for biodiesel production from waste cooking oil. Applied Catalysis A: General. 423-424: 1-6.

[19] Suppes, G.J., Bockwinkel, K., Lucas, S., Botts. J.B., Mason, M.H., Heppert, J.A. (2001). Calcium carbonate catalyzed alcoholysis of fats and oils. Journal American Oil Chemistry Society. 78(2): 139-145.

[20] Kim, H.J., Kang, B.S., Kim, Park, Y.M., Kim, D.K., Lee, J. S., Lee, K.Y. (2004). Transesterification M.J. of vegetable oil to biodiesel using heterogeneous base catalyst. Catalysis Today. 93-95: 315-320.

[21] Eckey, E.W. (1956). Esterification and interesterification. Journal American Oil Chemistry Society. 33: 575-579.

[22] Paola, M.G.D., Ricca, E., Calabrò, V., Curcio, S., Iorio, G. (2009). Factor analysis of transesterification reaction of waste oil for biodiesel production. Bioresource Technology 100: 5126-5131.

[23] Serio, M.D., Tesser, R., Pengmei, L., Santacesaria, E. (2008) Heterogeneous Catalysts for Biodiesel Production. Energy \& Fuels 22: 207-217.

[24] Koberg, M., Much, R.A., Gedanken, A. (2011). Optimization of bio-diesel production from soybean and wastes of cooked oil:Combining dielectric microwave irradiation and a $\mathrm{SrO}$ catalyst. Bioresource Technology. 102: 10731078.

[25] Liu, X., He, H., Wang, Y., Zhu, S. (2007). Transesterification of soybean oil to biodiesel using $\mathrm{SrO}$ as a solid base catalyst. Catalysis Communications. 8: 1107-1111.

[26] Chen, C.L., Huang, C.C., Tran, D.T., Changa, J.S. (2012). Biodiesel synthesis via heterogeneous catalysis using modified strontium oxides as the catalysts. Bioresource Technology 113: 8-13.

[27] Boro, J., Deka, D., Thakur, A.J. (2012). A review on solid oxide derived from waste shells as catalyst for biodiesel production. Renewable and Sustainable Energy Reviews. 16: 904-910.

[28] Vasudevan, P.T., Fu, B. (2010). Environmentally Sustainable Biofuels: Advances in Biodiesel Research, Waste and Biomass Valorization.1: 47-63.

[29] Aderemi, B.O., Hameed, B.H. (2009). Alum as a heterogeneous catalyst for the transesterification of palm oil. Applied Catalysis: A General. 370: 54-58.

[30] Ilgen, O. (2011). Dolomite as a heterogeneous catalyst for transesterification of canola oil. Fuel Processing Technology 92: 452-455.

[31] Ngamcharussrivichai, C., Nunthasanti, P., Tanachai. S., Bunyakiat, K. (2010). Biodiesel production through transesterification over natural calciums. Fuel Processing Technology. 91: 1409-1415.

[32] Ho, W.W.S., Ng, H.K., Gan, S. (2012). Development and characterisation of novel heterogeneous palm oil mill boiler ash-based catalysts for biodiesel production, Bioresource Technology. 125: 158-164.

[33] Ho, W.W.S., Ng, H.K., Gan,S., Tan, S. H. (2014). Evaluation of palm oil mill fly ash supported calcium oxide as a heterogeneous base catalyst in biodiesel synthesis from crude palm oil. Energy Conversion and Management, 88: 1167-1178. doi: 10.1016/ j.enconman.2014.03.061

[34] Boey, P.L., Ganesan, S., Lim, S. X., Lim, S.L., Maniam, G. P., Khairuddean, M. (2011). Utilization of BA (boiler ash) as catalyst for transesterification of palm olein. Energy. 36: 57915796.

[35] Chouhan, A.P.S., Sarma, A.K. (2013). Biodiesel production from Jatropha curcas L. oil using Lemna perpusilla Torrey ash as heterogeneous catalyst. Biomass and Bioenergy. 55: 386-389.

[36] Sharma, M., Khan, A.A., Puri, S.K., Tuli, D.K. (2012). Wood ash as a potential heterogeneous catalyst for biodiesel synthesis. Biomass and Bioenergy. 41: 94-106.

[37] Yaakob, Z., Sukarman, I.S.B., Narayanan, B., Abdullah, S.R.S., Ismail, M. (2012). Utilization of palm empty fruit bunch for the production of biodiesel from Jatropha curcas oil. Bioresource Technology. 104: 695-700.

[38] Chen, G.Y., Shan, R., Shi, J.F., Yan, B.B. (2015). Transesterification of palm oil to biodiesel using rice husk ash-based catalysts. Fuel Processing Technology. 133: 8-13.

[39] Vadery, V., Narayanan, B.N., Ramakrishnan, R.M., Cherikkallinmel, S.K., Sugunan, S., Narayanan, D.P., Sasidharan, S. (2014). Room 
temperature production of Jatropha biodiesel over coconut husk ash. Energy. 70: 588-594.

[40] Kumar, P., Aslam, M., Singh, N., Mittal, S., Bansal, A., Jha, M.K., Sarma, A.K. (2015).Characterization activity and process optimization with a biomass-based thermal power plant's fly ash as a potential catalyst for biodiesel production. RSC Advances. 5: 9946-9954.

[41] Sarma, A.K., Kumar, P., Aslam, M., Chouhan, A.P.S. (2014). Preparation and Characterization of Musa balbisiana Colla Underground Stem Nano-material for Biodiesel Production under Elevated Conditions. Catalysis Letters. 144 (7): 1344-1353.

[42] Chakraborty, R., Bepari, S., Banerjee, A. (2011). Application of calcined waste fish (Labeo rohita) scale as low-cost heterogeneous catalyst for biodiesel synthesis. Bioresource Technology. 102: 3610-3618.

[43] Obadiah, A., Swaroopa, G.A., Kumar, S.V., Jeganathan, K.R., Ramasubbu, A. (2012). Biodiesel production from Palm oil using calcined waste animal bone as catalyst Bioresource Technology. 116: 512-516.

[44] Farooq, M., Ramli, A., Naeem, A. (2015). Biodiesel production from low FFA waste cooking oil using heterogeneous catalyst derived from chicken bones. Renewable Energy 76: 362-368.

[45] Boro, J., Thakur, A.J., Deka, D. (2011). Solid oxide derived from waste shells of Turbonilla striatula as a renewable catalyst for biodiesel production. Fuel Processing Technology. 92: 2061-2067.

[46] Boro, J., Konwar, L.J., Thakur , A.J., Deka, D. (2014). Ba doped $\mathrm{CaO}$ derived from waste shells of $\mathrm{T}$ striatula (TS-CaO) as heterogeneous catalyst for biodiesel production, Fuel 129: $182-187$

[47] Empikul, N.V., Krasae, P., Nualpaeng, W., Yoosuk, B., Faungnawakij, K. (2012). Biodiesel production over Ca-based solid catalysts derived from industrial wastes, Fuel 92: 239-244.

[48] Hu, S., Wang,Y., Han, H. (2011). Utilization of waste freshwater mussel shell as an economic catalyst for biodiesel production. Biomass and Bioenergy. 35: 3627-3635.

[49] Suryaputra, W., Winata, I., Indraswati, N., Ismadji, S. (2013). Waste capiz (Amusium cristatum) shell as a new heterogeneous catalyst for biodiesel production. Renewable Energy 50: 795-799.

[50] Niju, S., Begum, K.M.M.S., Anantharaman, N. (2014). Continuous flow reactive distillation process for biodiesel production using waste egg shells as heterogeneous catalysts. RSC Advances. 4: 54109-54114.
[51] Xie, J., Zheng, X., Xiao A.D.Z., Zhang J. (2008). Biont shell catalyst for biodiesel production. Green Chemistry. 11: 355-364.

[52] Konwar, L.J., Arvel, P.M., Salminen, E., Kumar, N., Thakur, A.J., Mikkola, J.P., Deka, D. (2015). Towards carbon efficient biorefining: Multifunctional mesoporoussolid acids obtained from biodiesel production wastes for biomass conversion. Applied Catalysis B: Environmental. 176: 20-35.

[53] Konwar, L.J., Das, R., Thakur, A.J., Salminen, E., Arvela, P.M., Kumar, N., Mikkola, J.P., Deka, D. (2014). Biodiesel production from acid oils using sulfonated carbon catalyst derived from oil-cake waste, Journal of Molecular Catalysis A: Chemical 388-389: 167-176.

[54] Yang, L., Zhang, A., Zheng, X. (2009). Shrimp Shell Catalyst for Biodiesel Production. Energy \& Fuels. 23: 3859-3865.

[55] Shang, Y., Jiang, Y., Gao, Y. (2015). One-step Synthesis of Peanut Shell- derived Solid Acid for Biodiesel Production. Energy Sources Part A: Recovery, Utilization, and Environmental Effects. 37: 1039-1045.

[56] Turkay, S., Sevil, O,Y., Tolay, M., Serdar, E. (2006). Method of producing an adsorbent from rice hull ash. Patent US 20060269464 A1.

[57] Sarin, R., Arora, A.K., Puri, S.K., Prakash, S., Ranjan, R., Christopher, J., Tuli, D.K., Malhotra, R.K., Kumar, A. (2010). Novel catalyst composition for biodiesel production and process for preparing the same. Patent WO $2010113011 \mathrm{~A} 2$.

[58] Liu, J., Liu, H., Guo, X., Feng, Y., Hu, Z., Zhao, X., Wang, T., Li, X., Jingyu, J.G.L., Hui, L., Xuna, G., Yuan, F., Zhong, H., Xin, Z., Tao, W., Xueli, L., Junli, G. (2012). Catalyst used for preparation of biodiesel by using swill cooked dirty oil. Patent CN101985104 (B).

[59] Fang, L., Kerui, H., Huani, C., Jinlei, Z.(2013). Method for producing biodiesel through catalysis on municipal and industrial waste. Patent CN103396842 (A)

[60] Konwar, L.J., Mäki-Arvela, P., Salminen, E., Kumar, N., Thakur, A..J., Mikkola, J.P., Deka, D. (2015). Towards carbon efficient biorefining: Multifunctional mesoporous solid acids obtained from biodiesel production wastes for biomass conversion. Applied Catalysis B: Environmnetal, 176-177: 20-35. 